\title{
Osteoblasts Produce Soluble FactorsThat Induce a Gene Expression Pattern in Non-Metastatic Prostate Cancer Cells, Similar toThat Found in Bone Metastatic Prostate Cancer Cells
}

\author{
Zheng Fu, ${ }^{1}$ Igor M. Dozmorov, ${ }^{2}$ and Evan T. Keller ${ }^{1,2,3,4 *}$ \\ 'Program in Immunology, School of Medicine, University of Michigan, Ann Arbor, Michigan \\ ${ }^{2}$ Department of Pathology, School of Medicine, University of Michigan, Ann Arbor, Michigan \\ ${ }^{3}$ Unit for Laboratory Animal Medicine, School of Medicine, University of Michigan, Ann Arbor, Michigan \\ ${ }^{4}$ Connective Tissue Oncology Program, School of Medicine, University of Michigan, Ann Arbor, Michigan
}

\begin{abstract}
BACKGROUND. Progressive prostate cancer typically metastasizes to bone where prostate cancer cells gain an osteoblast-like phenotype and induce osteoblastic metastases through unknown mechanisms. To investigate the biology of prostate cancer skeletal metastases, we compared gene expression between the non-metastatic LNCaP cell line and its derivative cell line $\mathrm{C} 4-2 \mathrm{~B}$ that metastasizes to bone.

METHODS. Total RNA from LNCaP and C4-2B cell lines was isolated and used to probe membrane-based gene arrays (Comparison 1). Additionally, LNCaP cells were incubated in the absence or presence of conditioned media (CM) from a human osteoblast-like cell line (HOBIT) and total RNA from these cells was used to probe gene arrays (Comparison 2). Differential expression of genes was confirmed by RT-PCR.

RESULTS. Of the 1,176 genes screened, 35 were differentially expressed between LNCaP and C4-2B cells (Comparison 1). HOBIT-CM induced differential expression of 30 genes in LNCaP cells (Comparison 2). Interestingly, 19 genes that were differentially expressed in C4-2B vs. LNCaP also displayed a similar expression pattern in LNCaPs grown in HOBIT-CM. These genes are primarily involved in motility, metabolism, signal transduction, tumorigenesis, and apoptosis.

CONCLUSIONS. These results suggest that osteoblasts produce soluble factors that contribute to the progression of prostate cancer skeletal metastases, including their transition to an osteoblast-like phenotype. Additionally, these data provide targets to explore for further investigations towards defining the biology of skeletal metastases. Prostate 51: 10-20, 2002. (C) 2002 Wiley-Liss, Inc.
\end{abstract}

KEY WORDS: $\quad$ prostate cancer; metastasis; cDNA array; bone; osteoblast

\section{INTRODUCTION}

Prostate carcinoma is the most commonly diagnosed cancer in U.S. men, and is the second leading cause of cancer mortality in men over the age of 50 years in the United States [1]. Over 40,000 men die of this disease every year [2]. Prostate cancer frequently metastasizes to bone, with a $70-80 \%$ frequency in autopsy studies [3-6]. Bone metastasis is often associated with the development of hormone-refractory
Grant sponsor: USAMRMC Prostate Cancer Research Program; Grant number: DAMD17-00-1-053; Grant sponsor: NIH; Grant numbers: R01 AG15904, SPORE 1 P50 CA69568; Grant sponsor: Nathan Shock Center; Grant number: AG13283.

*Correspondence to: Evan T. Keller, Unit for Laboratory Animal Medicine, and Department of Pathology, University of Michigan School of Medicine, 1500 E. Medical Ctr. Dr., Ann Arbor, MI 481090940. E-mail: etkeller@umich.edu

Received 20 April 2001; Accepted 16 November 2001

DOI $10.1002 /$ pros.10056 
disease with poor prognosis. Patients with bone metastases commonly suffer from extreme pain, fractures, and spinal cord compression. The 5-year survival rate for patients with bone metastases is less than $50 \%$ [7]. Although skeletal metastases frequently occur in progressive prostate cancer, little is known about their pathophysiology.

The process of cancer progression is a direct result of aberrant expression of genes that impact normal cell growth. Thus, determining how gene expression profiles change during prostate cancer progression may contribute to our understanding of the mechanism of the development of skeletal metastases. Accordingly, in the current study, we have utilized high-density, nylon filter-based cDNA arrays to identify difference in gene expression between a nonmetastatic prostate cancer cell line, LNCaP, and its derivative bone-metastatic subline, C4-2B.

\section{MATERIALS AND METHODS}

\section{Cell Culture}

The non-metastatic LNCaP cell line was maintained in RPMI 10 medium (GIBCO-BRL, Grand Island, NY) supplemented with $10 \%$ fetal bovine serum (FBS) and $1 \%$ penicillin-streptomycin (GIBCO-BRL). The C4-2B cell line, an osteotropic metastatic derivative cell line of $\mathrm{LNCaP}$, was maintained in T medium $(80 \%$ Dulbecco's modified Eagle's medium (DMEM), 20\% F12, 3g/L NaCO $3,100 \mathrm{U} / \mathrm{L}$ penicillin G, $100 \mu \mathrm{g} / \mathrm{ml}$ streptomycin, $5 \mu \mathrm{g} / \mathrm{ml}$ insulin, $13.6 \mathrm{pg} / \mathrm{ml}$ triiodothyronine, $5 \mu \mathrm{g} / \mathrm{ml}$ transferrin, $0.25 \mu \mathrm{g} / \mathrm{ml}$ biotin, $25 \mu \mathrm{g} / \mathrm{ml}$ adenine), supplemented with 5\% FBS [8]. The HOBIT cell line, an SV-40-immortalized human osteoblast cell line [9], was maintained in HOBIT complete medium (50\% DMEM plus 50\% alpha medium supplemented with $10 \%$ FBS and $1 \%$ penicillin-streptomycin). HOBIT conditioned medium was prepared by plating HOBIT cells $\left(5 \times 10^{6}\right)$ in T-75 flasks in $20 \mathrm{ml}$ of HOBIT complete medium. Cells were grown to approximately $80 \%$ confluence (approximately $48 \mathrm{hr}$ ), then the growth medium was collected and FBS (to $10 \% \mathrm{v} / \mathrm{v}$ ) and fresh HOBIT complete medium (to $10 \% \mathrm{v} / \mathrm{v}$ ) was added. Prior to RNA extraction, LNCaP cells were switched into $\mathrm{T}$ medium for 10 days, or HOBITconditioned medium or HOBIT complete medium for 2 days as indicated.

\section{RNA Preparation and Labeling}

Cells were cultured to $70 \%$ confluence. Total RNA was extracted using the Atlas ${ }^{\mathrm{TM}}$ Pure Total RNA Isolation Kit (Clontech, Palo Alto, CA) as recommended by the manufacturer. The RNA was digested with RNase-free DNaseI to remove genomic DNA contamination. The yield and purity of RNA from various samples was estimated spectrophotometrically using the $A_{260} / A_{280}$ ratio. The quality of RNA was examined by the gel electrophoresis.

Reverse transcription, ${ }^{32}$ P-labeling and hybridization was carried out using the ATLAS cDNA Expression Array Kit (Clontech) as recommended by the manufacturer. Briefly, 2-5 $\mu$ g of total RNA was converted into ${ }^{32} \mathrm{P}$-labeled first strand $\mathrm{cDNA}$ by means of MMLV reverse transcriptase and purified using column chromatography (CHROMA SPIN-200; Clontech). cDNA-fractions of highest activity were pooled and hybridized to the Atlas Human 1.2 Array II membranes containing 1,176 spotted human cDNA fragments and nine housekeeping control cDNAs, and negative controls. The probe was heat denatured at $100^{\circ} \mathrm{C}$ for $2 \mathrm{~min}$ prior to hybridization.

\section{Hybridization}

After prehybridization of the array $(30 \mathrm{~min}$ at $68^{\circ} \mathrm{C}$ in ExpressHyb (Clontech) supplemented with $100 \mu \mathrm{g} / \mathrm{ml}$ sheared salmon testes DNA (Sigma, St. Louis, MO)), the heat-denatured probe was added. Hybridization was performed overnight at $68^{\circ} \mathrm{C}$ with continuous rolling agitation. Membranes were washed $4 \times 30 \mathrm{~min}$ in $2 \times \mathrm{SSC} / 1 \%$ SDS at $68^{\circ} \mathrm{C}$, followed by two washes in $0.1 \times \mathrm{SSC} / 0.5 \%$ SDS $\left(30 \mathrm{~min}, 68^{\circ} \mathrm{C}\right)$. Washed membranes were sealed in sample bags (Wallac, Finland) and subjected to storage phosphor screen imaging for 1-5 days using a PhosphorImager (Molecular Dynamics, Sunnyvale, CA) to view the image. Hybridization reactions were performed in duplicate.

\section{Data Acquisition and Analysis}

Each hybridized nylon array was used to produce two digital images, typically after different exposure times (1-5 days). Each digital image was converted into a table of pixel volumes using ImageQuant software (Molecular Dynamics). Two such tables were produced from each image, for a total of four tables from each mRNA sample; this redundancy was used to detect errors in digitization by comparison among the four replicate data sets, and rare errors were corrected by re-digitization of the original images. Average values from these quadruplicate digitizations were then used for further calculations.

Normalization for differences among experiments in exposure time, probe specific activity, probe quality, and other technical factors was conducted using a procedure described elsewhere [10]. In brief, the procedure assumes that spots corresponding to background (presumably for mRNAs not expressed by the cells) will be normally distributed. The mean $( \pm S D)$ 
pixel volume of these non-expressed genes were calculated with use of iterative truncation procedure. As a first approximation, the mean $( \pm S D)$ of all spots is calculated. Spots at the high and the low end of this distribution are then discarded one by one in alternating manner, if they exceed a criterion set 2 SDs above (for the spots at the high end) or below (for the spots at the low end) the mean of the remainder of the distribution. The resulting truncated set of points (typically $\sim 700$ of the initial set of 1,176) is then tested for normality using the Kolmogorov-Smirnov (KS) test, and points are again excluded, one at a time, beginning with points of higher pixel values, until the KS test indicates no further improvement in fit to normality. (We estimated the extent of improvement by calculating the KS distance (KSD), a gauge of how far data distribution deviated from a predicted normal distribution. This parameter decreases as the distribution approaches normality. Points with lower integrated pixel values are then excluded in the same way until the fit to the normal distribution is not improved by further steps (i.e., until the KSD decreases). The trimmed data set at this stage typically includes $650-700$ spots. We refer to this set of spots, trimmed to obtain optimal fit to a normal distribution, as the "background" set, and take it to represent the normal distribution of random intensities seen over those cDNA targets for which the test sample does not include detectable levels of complementary mRNA. After calculating the mean and SD for the set of normally distributed background spots, we can then assign each experimental value a normalized score $S$ using the formula: $\mathrm{S}=(\mathrm{PV}-\mathrm{Av}) / \mathrm{SD}$, where $\mathrm{PV}$ is the original pixel value for the spot, and Av and SD are the mean and standard deviation of the set of background spots. The distribution of $S$ has mean of zero and $\mathrm{SD}=1$ over the set of background genes. We accept $\mathrm{S}=3$, i.e., 3 SDs above the mean background level, as the preliminary criterion for discriminating expressed from non-expressed genes. We accept $S=-3$ as the criterion for discriminating non-expressed genes from those whose spots are distorted by proximity to a strongly expressed mRNA.

Comparing the levels of gene expression between two test samples cannot be based simply on the ratio between the paired pixel values, because this ratio will depend in part on uncontrolled experimental variables, including the quality of the mRNA preparation, the specific activity of the radionuclide, the efficiency of the probe labeling process and hybridization, and the background and exposure time for image development. Adjustment of these ratios can be accomplished using linear regression to transform the values to a comparable scale, as long as the regression equation is based upon genes that are expressed, and expressed to an equal extent, in both samples. Our strategy for formal classification of specific genes as equally expressed between test samples is based upon the analysis of the distribution of the ratios for expressed genes in the two experimental samples. Logarithms of ratios for expressed genes will have the shape of normal distribution altered in tail areas. The data set is then truncated at both ends, using the methods described above, to calculate the mean and variance of those ratios that conform to the normal distribution. The genes whose ratios belong to this normal distribution are considered to be equally expressed in both liver samples. These points are then fit to a linear regression equation of the form $S_{2}=$ $\mathrm{a}+\mathrm{b} * \mathrm{~S}_{1}$, where $\mathrm{a}$ and $\mathrm{b}$ are constants estimated by least squares regression. Calculation of $S_{2}^{\prime}=\left(S_{2}-a\right) / b$ then transforms each $S_{2}$ value to compensate for differences in technical variations between the two experiments. After such transformation, a plotting of each set of values on an axis of a two-dimensional coordinate system gives a useful impression about the relationship between expression profiles. All equally expressed genes will be normally distributed around straight line with $45^{\circ}$ slope passing through the origin. Differentially expressed genes will be represented by spots with higher deviation from the central line.

Another more convenient presentation of this interrelationship may be obtained if the regression line is used as an abscissa. All genes are presented now in the form of their deviations from equality. This form of the presentation excludes differences in the absolute expression of genes. Genes that are equally expressed in the two samples have ordinates that are normally distributes (according to KS criterion) with parameters mean $=0, \mathrm{SD}=0.066$. The degree to which a specific gene differs in its expression between two samples can conveniently be presented in the form of a ratio of the normalized data, or equivalently as the probability $(P)$ that the deviation (ordinate) for the specific gene belongs to the normal distribution of equally expressed genes with parameters mean $=0$, $\mathrm{SD}=0.066$. Presentation of new expression profiles in the form of deviations helps to concentrate attention on differences in expressions of genes rather than on their absolute values. Additionally, the statistical significance for each differential expression can be obtained in such a manner even from paired comparison of two samples.

Among the 1,176 genes in the array, $\sim 700$ were designated "non-expressed" in all samples, i.e., as genes never expressed at a level 3 standard deviations above background. Although it is possible that more sensitive methods might document expression of some of these genes, their level of expression was judged to be too low for reliable detection by the Clontech array 
A

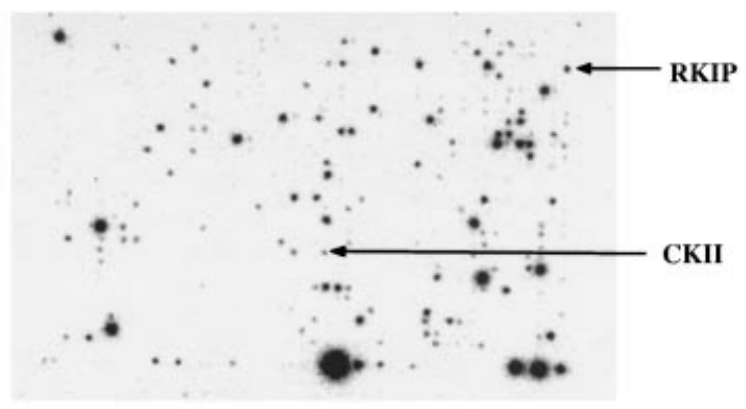

B

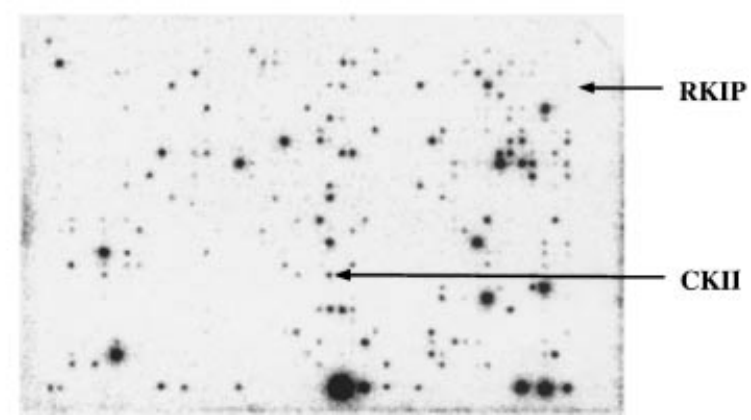

Fig. I. Expression profile of $\mathrm{LNCaP}(\mathbf{A})$ and $\mathrm{C} 4-2 \mathrm{~B}(\mathbf{B})$ prostate cancer cell lines. Gene expression in LNCaP (A) and C4-2B (B) cells was determined using Atlas cDNA array. Note that the Raf kinase inhibitory protein (RKIP) gene is down-regulated and the casein kinase II (CKII) gene is upregulated in C4-2B cells compared to LNCaP cells.

system. The remaining 400-500 genes are the subjects of this report.

\section{RT-PCR}

To confirm findings, select genes were subjected to RT-PCR. Briefly, $0.5 \mu \mathrm{g}$ of total RNA were reverse transcribed and PCR-amplified using the Access RT-PCR kit (Promega, Madison, WI). Sequences of PCR primers and PCR conditions will be provided on request. GAPDH, a housekeeping gene, served as an internal control.

\section{RESULTS}

To work toward defining the transition that promotes bone metastases, gene array technology was used to determine differences in gene expression between the non-metastatic $\mathrm{LNCaP}$ cell line and its bone-metastatic derivative cell line, $\mathrm{C} 4-2 \mathrm{~B}$. The $\mathrm{C} 4-2 \mathrm{~B}$ cell line was derived from osseous metastases of LNCaP cells that were repeatedly passed in nude mice $[11,12]$. When injected into SCID mice, C4-2B cells metastasize to bone and form mixed osteoblastic and osteolytic lesions $[12,13]$. Thus, the LNCaP and C4-2B cell lines represent a model of progression to prostate cancer skeletal metastasis.

To compare gene expression between these two cell lines, total RNA was isolated from $\mathrm{LNCaP}$ or C4-2B cells, and made into probes for hybridization. This was performed twice for each cell line to ensure consistency of results. The probes were hybridized to the Clontech Atlas human cDNA expression array II, which allows for direct screening of 1,176 cDNAs and includes nine additional genes (housekeeping genes) for normalization between hybridizations and three negative controls include lambda, M13, and plasmid (pUC18) DNA. Probes generated from LNCaP and $C 4-2 B$ cells were hybridized on two separate membranes (Fig. 1).

To evaluate the array results, spot densitometries were performed (see Materials and Methods) on the membranes hybridized with $\mathrm{C} 4-2 \mathrm{~B}$ or $\mathrm{LNCaP}$ probes. Densitometric values for each spot were normalized to the background and the two expression profiles were compared after re-scaling as described in Materials and Methods. The comparative analysis of two expression profiles obtained with RNA from two passages of LNCaP cells is presented in Figure 2. This figure is obtained from regression analysis of two samples and after axis transformation, in which the regression line becomes the abscissa and the ordinate is a measure of deviation from regression.

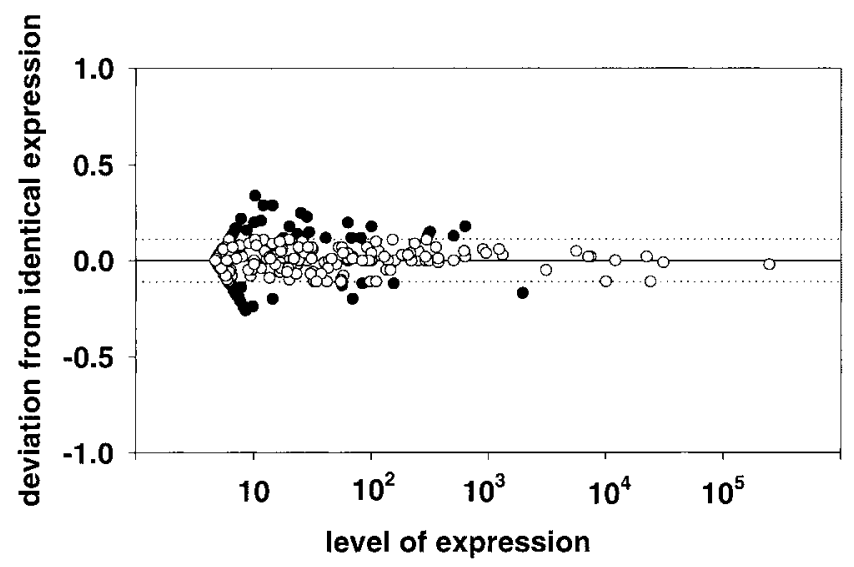

Fig. 2. Comparative analysis of similar data from the same source (RNA from different passages of the same cell line LNCaP). Each circle presents single gene. The abscissa characterizes the level of expression. The open circles represent genes that are equally expressed in both samples; their ordinates are characterized by a distribution with mean $=0$ and $\mathrm{SD}=0.066$. The dashed horizontal lines represent borders at $P=0.025$ and 0.975 . Filled circles correspond to the differentially expressed genes at this level of significance. 
Genes that are equally expressed in these two samples (clear circles) have ordinates that are normally distributed (according to KS criterion) with parameters mean $=0, S D=0.066$. The degree to which a specific gene differs in its expression between two samples can conveniently be presented in the form of a ratio of the normalized data (i.e., as $S_{2}^{\prime} / S_{1}$ ), together with the probability $(P)$ that the deviation from abscissa in Figure 2 for the specific gene belongs to the normal distribution of equally expressed genes.

The comparative analysis of these two samples from the same source (different passages of the same cell line) revealed 35 differentially expressed pairs above or below the borderlines for $P=0.025$ and 0.0975 . These genes may represent genes with natural high variability (related with cycle control for example) or expression that are different simply by chance. These genes were excluded from further comparative analysis of samples from different sources.

In the next step, a comparative analysis of gene expression between the $\mathrm{C} 4-2 \mathrm{~B}$ and $\mathrm{LNCaP}$ cell lines was performed (Comparison A, Fig. 1). After normalization and re-scaling of the gene expression profiles, we selected about 200 genes expressed in both samples above background (normalized expression $>3$ ). The significance of difference in expression of each gene can be determined as presented in Figure 2. Only genes with difference in expression above the significant threshold $P=0.025$ are presented in Table I. Thirty-five genes were identified that were differentially expressed. Of these 35 , approximately 10 of them (5\% of 200 expressed genes) could appear by chance only. For each gene in Table I, we calculated also the ratio of expressions in two examples.

Spots that were consistently changed in two separate experiments comparing $\mathrm{C} 4-2 \mathrm{~B}$ and $\mathrm{LNCaP}$ are reported in Table I. Some of the changes are of the order of 1.7-2.0; these may be of marginal physiological significance, but are included for completeness. Thirty-five cDNAs were found to be altered in a consistent manner, with 30 being up-regulated and 5 down-regulated in the C4-2B vs. LNCaP (Table I). As expected, the expressed housekeeping controls in row $G$ are also of similar relative intensity from one cell line to the other. mRNA expression profiles of those genes were confirmed by RT-PCR (Fig. 4; data not shown). The negative controls built into the membrane in the bottom row were all completely negative on all membranes (data not shown).

The environment in which prostate cancer grows may influence its phenotype [14]. Thus, we hypothesized that factors secreted by osteoblasts in the bone environment may promote a gene expression that contributes to the progression prostate cancer skeletal metastases. To test this hypothesis, we compared changes in gene expression between $\mathrm{LNCaP}$ cells grown in the absence and presence of conditioned medium from HOBIT (Comparison B). We found that 24 genes displayed a greater than two-fold increase in expression levels after HOBIT-conditioned medium treatment, whereas six genes displayed more than $50 \%$ decrease in gene expression (Table II). The negative controls built into the membrane in the bottom row were all completely negative on all membranes (data not shown).

We and others have previously documented that C4-2B cells take on an osteoblast-like phenotype $[15,16]$, which is consistent with the idea that the bone environment influences the prostate cancer cell gene expression. To determine if the bone environment influences the gene expression of prostate cancer cells, we compared changes in gene expression of the $\mathrm{C} 4-2 \mathrm{~B}$ cells vs. LNCaP cells to the changes in gene expression in LNCaP cells grown in HOBIT-conditioned media (CM) compared to HOBIT complete media (i.e., we compared Comparison A vs. Comparison B). We identified that 19 genes that were differentially expressed in $\mathrm{C} 4-2 \mathrm{~B}$ vs. LNCaP cells, displayed a similar expression pattern in LNCaP grown in HOBIT conditioned medium vs. the absence of CM (Fig. 3). RT-PCR was used to confirm the gene expression levels (Fig. 4). These genes and their functions are described in Table III.

\section{DISCUSSION}

The current study demonstrates that osteoblast-like cells produce soluble factors that induce a gene expression pattern in non-metastatic prostate cancer cells similar to that found in prostate cancer cells derived from bone metastases. This finding is consistent with the hypothesis that components of the bone environment, such as osteoblasts, contribute to the phenotype of prostate cancer skeletal metastases.

DNA array technology has been used to evaluate differences in gene expression prostate cancer tissues and cell lines [17-22]. The current report is the first evaluation of a non-metastatic cell line and its bonemetastatic derivative. Approximately thirty-five genes were found to be differentially expressed as confirmed by RT-PCR. These genes are involved in several important cellular events, including signal transduction, metabolism, transcription, and tumorigenesis. For example, our observation that calgizzarin mRNA, also called S100A11, was increased in the C4-2B cells may have pathophysiological importance. Specifically, calgizzarin is one of several genes expressed in breast cancer-derived metastatic axillary lymph nodes, but not in normal lymph nodes or breast fibroadenomas [23]. This implies that overexpression of S100A11 
TABLE I. List of Genes Differentially Expressed in C4-2B Vs. LNCaP Determined by cDNA Microarray Analyses

\begin{tabular}{|c|c|c|c|c|c|}
\hline Function & Coordinate & Genes & Accession no. & $P$ value & -Fold \\
\hline $\begin{array}{l}\text { Cytoskeleton and } \\
\text { motility proteins }\end{array}$ & F14c & $\begin{array}{l}\text { Atrophin-1; dentatorubral-oallidoluysian } \\
\text { atrophy protein (DRPLA) }\end{array}$ & D31840 & 0.000911 & 2.5 \\
\hline \multirow{2}{*}{$\begin{array}{l}\text { Extracellular } \\
\text { cell signaling \& } \\
\text { communication }\end{array}$} & E06a & $\begin{array}{l}\text { Similar to mouse growth/differentiation } \\
\text { factor } 7 \text { precursor (GDF7) }\end{array}$ & N32093 & 0.000251 & 0.2 \\
\hline & E06k & Natriuretic peptide precursor B (BNP) & M25296 & 0.000174 & 2.7 \\
\hline \multirow{3}{*}{$\begin{array}{l}\text { Cell adhesion } \\
\text { receptors } \\
\text { and proteins }\end{array}$} & B04b & Symplekin & U49240 & 0.000950 & * \\
\hline & B05i & $\begin{array}{l}\text { HLA-B-associated transcript 2; large } \\
\text { proline-rich protein BAT2 }\end{array}$ & M33509 & 0.000405 & 2.7 \\
\hline & B04n & $\begin{array}{l}\text { Antileukoproteinase } 1 \text { precursor (ALP); } \\
\text { HUSI-1; seminal proteinase inhibitor; } \\
\text { secretory leukocyte protease inhibitor; } \\
\text { BLO1; mucus proteinase inhibitor (MPI) }\end{array}$ & X04470 & 0.000001 & 4.9 \\
\hline \multirow{7}{*}{$\begin{array}{l}\text { Intracellular } \\
\text { transducers / } \\
\text { effectors/ } \\
\text { modulators }\end{array}$} & E08n & $\begin{array}{l}\text { Beta-adrenergic receptor kinase } 1 \\
\quad \text { (BARK1); G protein-coupled receptor } \\
\text { kinase } 2(\text { GRK2) }\end{array}$ & X61157 & 0.000353 & 7.3 \\
\hline & F03g & Calgizzarin; S100C protein; MLN70 & D38583 & 0.000456 & 2.8 \\
\hline & E081 & G protein-coupled receptor kinase 6 (GRK 6) & L16862 & 0.000023 & 4.0 \\
\hline & E09f & $\begin{array}{l}\text { Casein kinase II beta subunit (CKII); } \\
\text { phosvitin; CSNK2B }\end{array}$ & X16937 & 0.000986 & 2.6 \\
\hline & E08a & $\begin{array}{l}\text { Beta-adaptin 1; plasma membrane adaptor } \\
\text { HA/AP2 adaptin beta subunit; clathrin } \\
\text { assembly protein complex } 2 \text { beta large } \\
\text { subunit; AP105A; ATDB1; BAM22 }\end{array}$ & L13939 & 0.000998 & 2.2 \\
\hline & E08i & $\begin{array}{l}\text { Interleukin-1 receptor-associated kinase } \\
\quad \text { (IRAK) }\end{array}$ & L76191 & 0.000991 & 2.5 \\
\hline & F03n & $\begin{array}{l}\text { 14-3-3 protein epsilon (mitochondrial } \\
\text { import stimulation factor L subunit) } \\
\text { (protein kinase } C \text { inhibitor protein }-1 \text { ) }\end{array}$ & U28936 & 0.000358 & 6.2 \\
\hline \multirow[t]{7}{*}{ Metabolism } & C14d & $\begin{array}{l}\text { Phosphatidylethanolamine-binding protein } \\
\text { (PBP); Raf kinase inhibitor protein (RKIP) }\end{array}$ & D16111 & $1.03 \mathrm{E}-12$ & 0.3 \\
\hline & C14h & Farnesyl pyrophosphate synthetase & J05262 & 0.000895 & 2.6 \\
\hline & C14i & Squalene synthetase & X69141 & 0.000106 & 2.7 \\
\hline & C141 & MPD & U49260 & 0.000016 & 2.7 \\
\hline & $\mathrm{C} 09 \mathrm{n}$ & Lysosomal alpha-mannosidase & U60266 & 0.000979 & 2.3 \\
\hline & $\mathrm{C} 12 \mathrm{~g}$ & Peroxidase enoyl-CoA hydratase & U16660 & 0.000426 & 3.1 \\
\hline & D02n & Cytosolic thymidine kinase (Tk1) & K02581 & 0.000306 & 2.9 \\
\hline \multirow[t]{5}{*}{$\begin{array}{l}\text { Oncogenes and tumor } \\
\text { suppressors }\end{array}$} & $\mathrm{B} 09 \mathrm{~g}$ & $\begin{array}{l}\text { Cysteine-rich protein } 2 \text { (CRP2) } \\
\text { (ESP1 protein) }\end{array}$ & D42123 & 0.000245 & 6.0 \\
\hline & $\mathrm{B} 11 \mathrm{~b}$ & Ras-related protein RAB-8; oncogene c-mel & X56741 & 0.000002 & 6.2 \\
\hline & B10g & $\begin{array}{l}\text { Nuclear pore complex protein } 214 \\
\text { (NUP214); CAN protein }\end{array}$ & X64228 & 0.000963 & 3.3 \\
\hline & B08h & Zinc finger protein hrx; ALL-1; MLL & L04284 & 0.000993 & 4.1 \\
\hline & B09d & AF-17 protein & U07932 & 0.000899 & 1.9 \\
\hline \multirow[t]{4}{*}{$\begin{array}{l}\text { Trafficking/targeting } \\
\text { proteins }\end{array}$} & C04k & $\begin{array}{l}\text { ER lumen protein retaining receptor } 1 \text {; } \\
\text { KDEL receptor } 1 \text {; ERD21 }\end{array}$ & X55885 & 0.000977 & 3.0 \\
\hline & C06k & Syntaxin 3 (STX3) & U32315 & 0.000060 & 4.4 \\
\hline & $\mathrm{C} 03 n$ & ADP-ribosylation factor 1 & M36340 & 0.000986 & 3.2 \\
\hline & C07d & Ras-related protein RAB-11B; YPT3 & X79780 & 0.000946 & 0.5 \\
\hline \multirow[t]{3}{*}{ Transcription (factors) } & $\mathrm{B} 02 \mathrm{a}$ & Cysteine-rich protein 1 (CRP1) & M33146 & 0.000001 & 2.7 \\
\hline & A091 & Hepatocyte nuclear factor 3-alpha (HNF-3 $\alpha$ ) & U39840 & 0.000866 & 2.4 \\
\hline & A11d & Homeobox protein NKX-3.1 & U80669 & 0.000898 & 1.9 \\
\hline
\end{tabular}


TABLE I. (Continued)

\begin{tabular}{|c|c|c|c|c|c|}
\hline Function & Coordinate & Genes & Accession no. & $P$ value & -Fold \\
\hline & $\mathrm{A} 13 \mathrm{c}$ & $\begin{array}{l}\text { SREBP-1-basic-helix-loop-helix-leucine } \\
\text { zipper protein }\end{array}$ & U00968 & 0.000988 & 1.7 \\
\hline & A01b & $\begin{array}{l}\text { CD81 antigen; } 26-\mathrm{kDa} \text { cell surface protein } \\
\text { TAPA-1 }\end{array}$ & M33680 & 0.000913 & 0.5 \\
\hline
\end{tabular}

This table was generated from a comparison of RNA from osteogenic C4-2B and non-osteogenic LNCaP. This assay was repeated and the similar results were observed.

*Stands for the genes which only detected in C4-2B, but not in LNCaP.

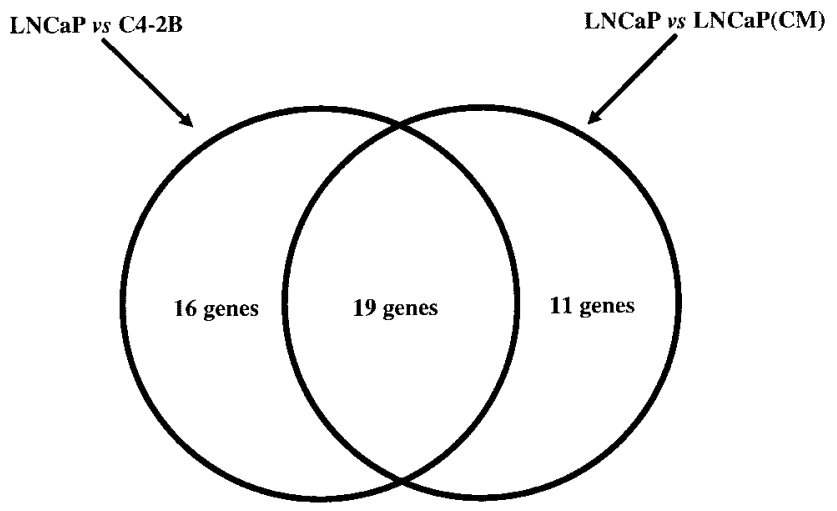

Fig. 3. Similarity of genes that are differentially expressed in $\mathrm{LNCaP}$ vs. C4-2B and LNCaP vs. LNCaP grown in osteoblast cell$\mathrm{CM}$. The overlap indicates the genes that are similarly regulated between the two comparisons. These data were derived from Tables I and II.

might be of importance in the cancer progression and metastasis process. Interestingly, one of its family members, S100A4, has been shown to be closely related to metastasis of several cancers [24-26]. Another example of the potential implication of these data is the observation of increased mevalonate pyrophosphate decarboxylase (MPD) mRNA expression in the C4-2B cells. MPD is involved in the isoprenoid synthetic pathway, which is critical for cell growth, and inhibition MPD using phenylacetate diminished growth of a variety of tumors [27]. Thus, these data have the potential to provide target molecules to investigate the molecular basis for the progression of prostate cancer metastasis.

The mechanism through which prostate cancer metastasizes to the bone is undefined (reviewed in [28-30]). The "seed-and-soil" theory proposed by Paget emphasizes the importance of host milieu ("soil") that determines the selectivity of cancer metastasis ("seed") [31]. In prostate cancer metastases, it is likely that a reciprocal interaction mediated by bone remodeling factors, growth factors, and extracellular matrices occurs between prostate cancer cells and bone cells. This hypothesis is supported by the observation that HOBIT cell CM influenced gene expression in LNCaP cells. The interaction between prostate cancer cells and their target tissue has been previously demonstrated. For example, a critical interaction between prostatic epithelium and organ-specific stromal cells contributes to the androgen-independent progression of prostate cancer and acquisition of metastatic potential to skeleton and lymph nodes [11,32].

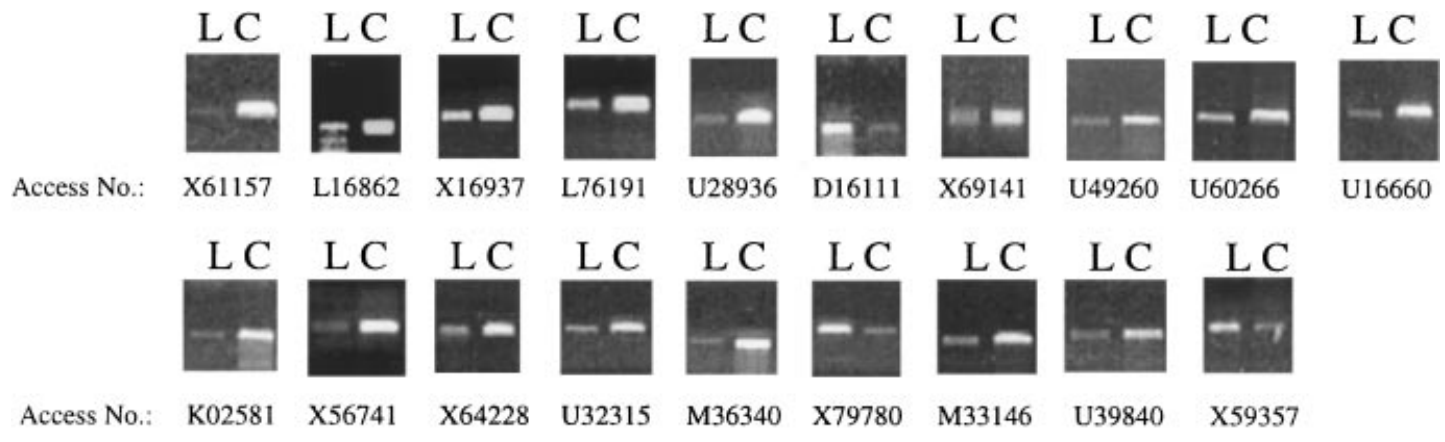

Fig. 4. RT-PCR analysis of genes that demonstrate similar patterns of expression in LNCaPvs. C4-2B compared to LNCaP vs. LNCaP grown in osteoblast cell-CM. Total RNA was obtained from LNCaP (L) or C4-2B (C) cells and subjected to RT-PCR. Genes are described by their Genbank accession number. The gene names and properties can be found in Table III. 
TABLE II. List of Genes Differentially Expressed in LNCaP(CM)Vs. LNCaP Determined by cDNA Microarray Analyses

\begin{tabular}{|c|c|c|c|c|c|}
\hline Function & Coordinate & Genes & Accession no. & $P$ value & -Fold \\
\hline $\begin{array}{l}\text { Cell adhesion receptors } \\
\text { and proteins }\end{array}$ & B05i & $\begin{array}{l}\text { HLA-B associated transcript 2; large } \\
\text { proline-rich protein BAT2 }\end{array}$ & M33509 & 0.000995 & 2.0 \\
\hline \multirow[t]{5}{*}{$\begin{array}{l}\text { Intracellular transducers / } \\
\text { effectors / modulators }\end{array}$} & E08n & $\begin{array}{l}\text { Beta-adrenergic receptor kinase } 1 \\
\text { (BARK1); G protein-coupled } \\
\text { receptor kinase } 2 \text { (GRK2) }\end{array}$ & X61157 & 0.000044 & 17.6 \\
\hline & E081 & $\begin{array}{l}\text { G protein-coupled receptor kinase } 6 \\
\text { (GRK6) }\end{array}$ & L16862 & 0.000938 & 4.0 \\
\hline & E09f & $\begin{array}{l}\text { Casein kinase II beta subunit (CKII); } \\
\text { phosvitin; CSNK2B }\end{array}$ & X16937 & 0.000920 & 2.0 \\
\hline & E08i & $\begin{array}{l}\text { Interleukin-1 receptor-associated kinase } \\
\text { (IRAK) }\end{array}$ & L76191 & 0.000008 & 3.6 \\
\hline & F03n & $\begin{array}{l}\text { 14-3-3 protein epsilon (mitochondrial } \\
\text { import stimulation factor L subunit) } \\
\text { (protein kinase C inhibitor protein-1) }\end{array}$ & U28936 & 0.000958 & 2.0 \\
\hline \multirow[t]{9}{*}{ Metabolism } & C14d & $\begin{array}{l}\text { Phosphatidylethanolamine-binding } \\
\text { protein (PBP); Raf kinase inhibitor } \\
\text { protein (RKIP) }\end{array}$ & D16111 & $1.14 \mathrm{E}-11$ & 0.2 \\
\hline & C141 & $\begin{array}{l}\text { Mevalonate pyrophosphate } \\
\text { decarboxylase (MPD) }\end{array}$ & U49260 & 0.000160 & 2.2 \\
\hline & $\mathrm{C} 09 \mathrm{n}$ & Lysosomal alpha-mannosidase & U60266 & 0.000983 & 2.4 \\
\hline & $\mathrm{C} 12 \mathrm{~g}$ & Peroxidase enoyl-CoA hydratase & U16660 & 0.000996 & 2.0 \\
\hline & D02n & Cytosolic thymidine kinase (TK1) & K02581 & 0.000002 & 2.2 \\
\hline & $\mathrm{C} 11 \mathrm{~m}$ & $\begin{array}{l}\text { Mitochondrial ATP synthase alpha chain } \\
\text { precursor; ATP5A1 }\end{array}$ & D14710 & 0.000981 & 2.7 \\
\hline & $\mathrm{C} 13 \mathrm{j}$ & $\begin{array}{l}\text { Brain-form phosphoglycerate mutase; } \\
\text { PGAM-B; BPG-dependent PGAM }\end{array}$ & J04173 & $1.38 \mathrm{E}-08$ & 0.2 \\
\hline & D05f & $\begin{array}{l}\text { Lysosomal acid phosphatase precursor } \\
\text { (LAP); ACP2 }\end{array}$ & X12548 & 0.000404 & 0.5 \\
\hline & $\mathrm{C} 14 \mathrm{i}$ & Squalene synthetase & X69141 & 0.000780 & 0.2 \\
\hline \multirow[t]{3}{*}{$\begin{array}{l}\text { Oncogenes and tumor } \\
\text { suppressors }\end{array}$} & B11b & $\begin{array}{l}\text { Ras-related protein } \mathrm{RAB}-8 \text {; oncogene } \\
\text { c-mel }\end{array}$ & X56741 & 0.000917 & 5.5 \\
\hline & $\mathrm{B} 10 \mathrm{~g}$ & $\begin{array}{l}\text { Nuclear pore complex protein } 214 \\
\text { (NUP214); CAN protein }\end{array}$ & X64228 & 0.000968 & 3.2 \\
\hline & B07f & Breakpoint cluster region protein (BCR) & X02596 & 0.000305 & 2.0 \\
\hline \multirow{5}{*}{$\begin{array}{l}\text { Trafficking/targeting } \\
\text { proteins }\end{array}$} & C06k & Syntaxin 3 (STX3) & U32315 & 0.000945 & 3.6 \\
\hline & $\mathrm{C} 03 n$ & ADP-ribosylation factor 1 & M36340 & 0.000997 & 2.0 \\
\hline & $\mathrm{C} 07 \mathrm{~d}$ & Ras-related protein RAB-11B; YPT3 & X79780 & 0.000140 & 0.5 \\
\hline & C081 & Syntaxin 5 (STX5) & U26648 & 0.000981 & 2.6 \\
\hline & $\mathrm{C} 03 \mathrm{~h}$ & Ras-related protein RAB-5C & U18420 & 0.000993 & 2.0 \\
\hline \multirow[t]{3}{*}{ Transcription (factors) } & $\mathrm{B} 02 \mathrm{a}$ & Cysteine-rich protein 1 (CRP1) & M33146 & 0.000968 & 2.0 \\
\hline & A091 & $\begin{array}{l}\text { Hepatocyte nuclear factor 3-alpha } \\
(\mathrm{HNF}-3 \alpha)\end{array}$ & U39840 & 0.000977 & 2.0 \\
\hline & B02k & MEL-18 ring-finger protein & D13969 & 0.000862 & 4.0 \\
\hline \multirow[t]{4}{*}{ Others } & D07e & 60s ribosomal protein L22 (RPL22) & X59357 & 6.64E-05 & 0.5 \\
\hline & F07a & Cathepsin D precursor (CTSD) & M11233 & 0.000931 & 2.0 \\
\hline & D07a & $\begin{array}{l}\text { Platelet-activating factor acetylhydrolase } \\
\text { IB gamma subunit }\end{array}$ & D63391 & 0.000988 & 2.5 \\
\hline & D14d & Ubiquitously expressed nuclear receptor & U07132 & 0.000999 & 2.4 \\
\hline
\end{tabular}

This table was generated from a comparison of RNA from LNCaP grown in Hobit condition medium and regular LNCaP. This assay was repeated and similar results were observed. 
TABLE III. Gene Expression ChangesThat Are Similar in Both C4-2B Cells and LNCaP Cells Grown in Osteoblast-Like Cell Conditioned Medium

\begin{tabular}{|c|c|c|c|}
\hline Genes & Accession no. & Change & Functions \\
\hline $\begin{array}{l}\text { Beta-adrenergic kinase } 1 \\
\quad(B A R K 1) ; G \text { protein-coupled } \\
\text { receptor kinase } 2 \text { (GRK2) }\end{array}$ & X61157 & $\uparrow$ & $\begin{array}{l}\text { A ubiquitous cytosolic enzyme that specifically phosphorylates } \\
\text { the activated form of the beta-adrenergic and related } \\
\text { G-protein-coupled receptors }\end{array}$ \\
\hline $\begin{array}{l}\text { G protein-coupled receptor } \\
\text { kinase } 6 \text { (GRK6) }\end{array}$ & L16862 & $\uparrow$ & $\begin{array}{l}\text { Plays an important role in phosphorylating and regulating } \\
\text { the activity of a variety of } G \text { protein-coupled receptors }\end{array}$ \\
\hline $\begin{array}{l}\text { Casein kinase II beta subunit } \\
\text { (CKII); phosvitin; CSNK2B }\end{array}$ & X16937 & $\uparrow$ & $\begin{array}{l}\text { A ubiquitous messenger-independent serine/threonine } \\
\text { kinase, localized in both the cytoplasm and the nucleus }\end{array}$ \\
\hline $\begin{array}{l}\text { Interleukin-1 receptor-associated } \\
\text { kinase (IRAK) }\end{array}$ & L76191 & $\uparrow$ & $\begin{array}{l}\text { A kinase associated with interleukin-1 receptor and } \\
\text { participates in IL-1 and IL-18 signal transduction }\end{array}$ \\
\hline $\begin{array}{l}\text { 14-3-3 protein epsilon } \\
\text { (mitochondrial import } \\
\text { stimulation factor L subunit) } \\
\text { (protein kinase C inhibitor } \\
\text { protein-1) }\end{array}$ & U28936 & $\uparrow$ & $\begin{array}{l}\text { Plays key functional roles in many critical physiological } \\
\text { pathways that are regulated by phosphorylation. It binds } \\
\text { to the phosphorylated target, which completes a change } \\
\text { in structure that regulates activity }\end{array}$ \\
\hline $\begin{array}{l}\text { Phosphatidylethanolamine- } \\
\text { binding protein (PBP); Raf } \\
\text { kinase inhibitor protein (RKIP) }\end{array}$ & D16111 & $\downarrow$ & $\begin{array}{l}\text { Is the precursor of the hippocampal neurostimulating peptide, } \\
\text { which enhances the synthesis of choline acetyltransferase. } \\
\text { In addition, it inhibits the phosphorylation and activation } \\
\text { of MEK by RAF1 }\end{array}$ \\
\hline Squalene synthetase & X69141 & $\uparrow$ & $\begin{array}{l}\text { Catalyzes the reductive head-to-head condensation of } \\
\text { two molecules of farnesyl diphosphate to from squalene, } \\
\text { the first specific intermediate in the cholesterol } \\
\text { biosynthetic pathway }\end{array}$ \\
\hline MPD & U49260 & $\uparrow$ & $\begin{array}{l}\text { Catalyzes the conversion of mevalonate pyrophosphate } \\
\text { into isopentenyl pyrophosphate, which is one of the early } \\
\text { steps in cholesterol biosynthesis }\end{array}$ \\
\hline Lysosmal alpha-mannosidase & U60266 & $\uparrow$ & $\begin{array}{l}\text { Required for the degradation of } N \text {-linked carbohydrates } \\
\text { during glycoprotein catabolism in eukaryotic cells }\end{array}$ \\
\hline Peroxidase enoyl-CoA hydratase & U16660 & $\uparrow$ & One of the enzymes of the peroxisomal beta-oxidation system \\
\hline Cytosolic thymidine kinase (TK1) & K02581 & $\uparrow$ & $\begin{array}{l}\text { Catalyzes the phosphorylation of thymidine to } \\
\text { deoxythymidine monophosphate }\end{array}$ \\
\hline $\begin{array}{l}\text { Ras-related protein RAB-8; } \\
\text { oncogene c-mel }\end{array}$ & X56741 & $\uparrow$ & $\begin{array}{l}\text { May play a role in the transport of proteins from the } \\
\text { endoplasmic reticulum to the Golgi and the plasma } \\
\text { membrane }\end{array}$ \\
\hline $\begin{array}{l}\text { Nuclear pore complex protein } 214 \\
\quad(\text { NUP214); CAN protein }\end{array}$ & X64228 & $\uparrow$ & $\begin{array}{l}\text { An FXFG repeat-containing protein involved in myeloid } \\
\text { leukemia in humans. It is a component of the } \\
\text { vertabrate nucleopore complex (NPC), a 125-megadalton } \\
\text { multiprotein assembly that mediates nucleocytoplasmic } \\
\text { transport }\end{array}$ \\
\hline Syntaxin 3 (STX3) & U32315 & $\uparrow$ & $\begin{array}{l}\text { A cellular receptor for transport vesicles and one of } \\
\text { major components of vesicle trafficking }\end{array}$ \\
\hline ADP-ribosylation factor 1 & M36340 & $\uparrow$ & $\begin{array}{l}\text { A guanine nucleotide-binding protein that stimulates } \\
\text { cholera toxin ADP-ribosyltransferase activity and is } \\
\text { involved in vesicular transport and functioning as } \\
\text { activators of phospholipase D }\end{array}$ \\
\hline $\begin{array}{l}\text { Ras-related protein } \\
\text { RAB-11B;YPT3 }\end{array}$ & X79780 & $\downarrow$ & $\begin{array}{l}\text { Plays a critical role in regulating exocytotic and } \\
\text { endocytotic pathways }\end{array}$ \\
\hline Cysteine-rich protein 1 (CRP1) & M33146 & $\uparrow$ & $\begin{array}{l}\text { A highly conserved, cell cycle-regulated gene that is induced } \\
\text { in the immediate early response to serum repletion in } \\
\text { serum-starved, noncycling cells }\end{array}$ \\
\hline $\begin{array}{l}\text { Hepatocyte nuclear factor } \\
\text { 3-alpha (HNF-3 } \alpha)\end{array}$ & U39840 & $\uparrow$ & A member of the forkhead class of DNA-binding proteins \\
\hline $\begin{array}{l}\text { 60s ribosomal protein } \\
\text { L22 (RPL22) }\end{array}$ & X59357 & $\downarrow$ & $\begin{array}{l}\text { One of the five proteins necessary for the formation of an } \\
\text { early intermediate of the } 23 S \text { rRNA in the assembly of } \\
\text { the large ribosomal subunit }\end{array}$ \\
\hline
\end{tabular}


Additionally, it has been shown that either soluble growth factors or extracellular matrices play an essential role in affecting cancer epithelium growth and differentiation and that interruption of this interaction abrogates cancer cell growth and delayed disease progression [33].

We and others have previously documented that C4-2B cells possess an osteoblast-like phenotype, including the ability to mineralize and express the osteoblastic transcription factor Cbfa1 $[15,16]$. This observation is consistent with the idea that the bone environment influences prostate cancer cell gene expression as previously proposed [34]. Several proteins have been implicated in the production of osteoblastic metastases in prostate cancers including urokinase [35] and endothelin-1 [36]. The observation that HOBIT-CM induced a similar gene expression pattern in LNCaP cells as observed in C4-2B cells suggests that the bone environment is an important influence on prostate cancer skeletal metastases. The genes expression modulated by the HOBIT-CM or present in C42B vs. LNCaP cells (Table III) encompass a wide variety of functions. Several of these genes may provide a growth advantage to prostate cancer cells in the bone environment through enhancement of overall tumor cell growth or a proliferative effect or prevention of apoptosis. The function of these genes in prostate cancer is not known at this time; however, these findings provide the foundation for future studies. A limitation of this study is the cell models used. For example, although C4-2B cells metastasize to bone, their metastatic rate is low (approximately 15-25\%), and they metastasize to sites other than bone. Thus, several of the changes in gene expression we observed may not be specific to bone metastases.

In conclusion, we identified that changes in gene expression during prostate cancer progression to a metastatic phenotype and after exposure to osteoblastproduced soluble factors have some similarities. Our data support the contention that soluble factors present in the bone microenvironment contribute, in part, to the progression of prostate cancer skeletal metastases. In addition to identifying genes that may contribute to prostate cancer progression, these findings have enhanced our awareness of the large repertoire of genes and the multiple cell processes and signaling pathways altered in prostate cancer skeletal metastases.

\section{REFERENCES}

1. Landis SH, Murray T, Bolden S, Wingo PA. Cancer statistics. CA Cancer J Clin 1998;48:6-29.

2. Jacob S. Spread of prostate cancer to bone. J Urol 1983;21:337344.
3. Harada M, Iida M, Yamaguchi M, Shida K. Kerr Yamanaka, editors. Analysis of bone metastasis of prostatic adenocarcinoma in 137 autopsy cases. New York: Plenum Press; 1992. 173-182 p.

4. Mintz E, Smith G. Autopsy findings in 100 cases of prostate cancer. N Engl J Med 1934;211:479-487.

5. Franks L. The spread of prostate cancer. J Pathol Bacteriol 1956;72:603-611.

6. Zetter BR. The cellular basis of site-specific tumor metastasis. N Engl J Med 1990;322:605-612.

7. Pound CR, Partin AW, Eisenberger MA, Chan DW, Pearson JD, Walsh PC. Natural history of progression after PSA elevation following radical prostatectomy. JAMA 1999;281:1591-1597.

8. Dong JT, Suzuki H, Pin SS, Bova GS, Schalken JA, Isaacs WB, Barrett JC, Isaacs JT. Down-regulation of the KAI1 metastasis suppressor gene during the progression of human prostatic cancer infrequently involves gene mutation or allelic loss. Cancer Res 1996;56:4387-4390.

9. Keeting PE, Scott RE, Colvard DS, Anderson MA, Oursler MJ, Spelsberg TC, Rigg BL. Development and characterization of a rapidly proliferating, well-differentiated cell line derived from normal adult human osteoblast-like cells transfected with SV40 large T antigen. J Bone Miner Res 1992;7:127-136.

10. Dozmorov I, Bartke A, Miller RA. Array-based expression analysis of mouse liver genes: effect of age and of the longevity mutant Prop1df. J Gerontol A Biol Sci Med Sci 2001;56:B72-B80.

11. Wu HC, Hsieh JT, Gleave ME, Brown NM, Pathak S, Chung LW. Derivation of androgen-independent human LNCaP prostatic cancer cell sublines: role of bone stromal cells. Int J Cancer 1994;57:406-412.

12. Thalmann GNN, Sikes RA, Wu TT, Degeorges A, Chang SM, Ozen M, Pathak S, Chung LW. LNCaP progression model of human prostate cancer: androgen-independence and osseous metastasis. Prostate 2000;44:91-103.

13. Zhang J, Dai J, Smith P, Qi Y, Lin D, Strayhorn C, Mizokami A, $\mathrm{Fu} \mathrm{Z}$, Keller E. Osteoprotegerin inhibits prostate cancerinduced osteoclastogenesis and prevents prostate tumor growth in the bone of mice. J Clin Invest 2001;1235-1241.

14. Chung LW, Davies R. Prostate epithelial differentiation is dictated by its surrounding stroma. Mol Biol Rep 1996;23:13-19.

15. Chung LW. The role of stromal-epithelial interaction in normal and malignant growth. Cancer Surv 1995;23:33-42.

16. Lin D, Tarnowski C, Patel A, Rohn E, Morris M, Keller E. The bone metastatic LNCaP-derivative C4-2B prostate cancer cell line induces mineralization in vitro. Prostate 2001;47:212221.

17. Bubendorf L, Kolmer M, Kononen J, Koivisto P, Mousses $S$, Chen Y, Mahlamaki E, Schraml P, Moch H, Willi N. Hormone therapy failure in human prostate cancer: analysis by complementary DNA and tissue microarrays. J Natl Cancer Inst 1999;91:1758-1764.

18. Xu J, Stolk JA, Zhang X, Silva SJ, Houghton RL, Matsumura M, Vedvick TS, Leslie KB, Badaro R, Reed SG. Identification of differentially expressed genes in human prostate cancer using subtraction and microarray. Cancer Res 2000;60:1677-1682.

19. Elek J, Park KH, Narayanan R. Microarray-based expression profiling in prostate tumors. In Vivo 2000;14:173-182.

20. Carlisle AJ, Prabhu VV, Elkahloun A, Hudson J, Trent JM, Linehan WM, Williams ED, Emmert-Buck MR, Liotta LA, Munson PJ, Krizman DB. Development of a prostate cDNA microarray and statistical gene expression analysis package. Mol Carcinog 2000;28:12-22. 
21. Vaarala MH, Porvari K, Kyllonen A, Vihko P. Differentially expressed genes in two LNCaP prostate cancer cell lines reflecting changes during prostate cancer progression. Lab Invest 2000;80:1259-1268.

22. Chetcuti A, Margan S, Mann S, Russell P, Handelsman D, Rogers J, Dong Q. Identification of differentially expressed genes in organ-confined prostate cancer by gene expression array. Prostate 2001;47:132-140.

23. Tomasetto C, Regnier C, Moog-Lutz C, Mattei MG, Chenard MP, Lidereau R, Basset P, Rio MC. Identification of four novel human genes amplified and overexpressed in breast carcinoma and localized to the q11-q21.3 region of chromosome 17. Genomics 1995;28:367-376.

24. Bjornland K, Winberg JO, Odegaard OT, Hovig E, Loennechen T, Aasen AO, Fodstad O, Maelandsmo GM. S100A4 involvement in metastasis: deregulation of matrix metalloproteinases and tissue inhibitors of matrix metalloproteinases in osteosarcoma cells transfected with an anti-S100A4 ribozyme. Cancer Res 1999;59:4702-4708.

25. Takenaga K, Nakanishi H, Wada K, Suzuki M, Matsuzaki O, Matsuura A, Endo H. Increased expression of S100A4, a metastasis-associated gene, in human colorectal adenocarcinomas. Clin Cancer Res 1997;3:2309-2316.

26. Takenaga K, Nakamura Y, Sakiyama S. Expression of antisense RNA to S100A4 gene encoding an S100-related calcium-binding protein suppresses metastatic potential of high-metastatic Lewis lung carcinoma cells. Oncogene 1997;14:331-337.

27. Harrison LE, Wojciechowicz DC, Brennan MF, Paty PB. Phenylacetate inhibits isoprenoid biosynthesis and suppresses growth of human pancreatic carcinoma. Surgery 1998;124:541-550.
28. Lange PH, Vessella RL. Mechanisms, hypotheses and questions regarding prostate cancer micrometastases to bone. Cancer Metastasis Rev 1998;17:331-336.

29. Boyce BF, Yoneda T, Guise TA. Factors regulating the growth of metastatic cancer in bone. Endocr Relat Cancer 1999;6:333347.

30. Yoneda T. Cellular and molecular mechanisms of breast and prostate cancer metastasis to bone. Eur J Cancer 1998;34:240245.

31. Paget $\mathrm{S}$. The distribution of secondary growths in cancer of the breast. Lancet 1889;1:571-573.

32. Gleave M, Hsieh JT, Gao CA, von Eschenbach AC, Chung LW. Acceleration of human prostate cancer growth in vivo by factors produced by prostate and bone fibroblasts. Cancer Res 1991;51:3753-3761.

33. Thalmann G, Anezinis P, Chung L, Devoll R, Farach-Carson C. Experimental approached to skeletal metastasis of human prostate cancer. Principles Pract Genitourin Oncol 1997;409416.

34. Koeneman KS, Yeung F, Chung LW. Osteomimetic properties of prostate cancer cells: a hypothesis supporting the predilection of prostate cancer metastasis and growth in the bone environment. Prostate 1999;39:246-261.

35. Goltzman D. Mechanisms of the development of osteoblastic metastases. Cancer 1997;80:1581-1587.

36. Chiao JW, Moonga BS, Yang YM, Kancherla R, Mittelman A, Wu-Wong JR, Ahmed T. Endothelin-1 from prostate cancer cells is enhanced by bone contact which blocks osteoclastic bone resorption. Br J Cancer 2000;83:360365. 